American Journal of Pharmaceutical Education 2019; 83 (2) Article 6513.

\title{
RESEARCH
}

\section{Publication Records and Bibliometric Indices of Pharmacy School Deans}

\author{
Dennis F. Thompson, PharmD \\ Submitted May 10, 2017; accepted August 23, 2017; published March 2019.
}

Objective. To characterize the publication records and bibliometric indices of current CEO deans at pharmacy schools and colleges in the United States.

Methods. Using the Web of Science database, the publication records of all CEO pharmacy deans in the US were collected. Bibliometric indices calculated included: lifetime publications, publications/ year, h-index, m-quotient, lifetime citations, citations/year, average citations/paper, productivity, and creativity. The Kruskal-Wallis analysis of variance for nonparametric data was used to assess differences between groups.

Results. All bibliometric parameters were different between pharmacy schools and colleges that were research-intensive vs teaching-intensive, academic health center-based vs non-academic health centerbased, and public vs private. Additionally, the discipline and degree of each dean yielded significant differences. There were no significant differences in bibliometric parameters between male or female deans.

Conclusion. Deans of current SCOP display a varied range of publication records and bibliometric indices.

Keywords: publications, scholarship, faculty, pharmacy deans

\section{INTRODUCTION}

Teaching, research, and service have historically served as the cornerstone of higher education. Boyer has expanded our understanding of research to include not only the scholarship of discovery but also the scholarship of integration, teaching, and application. ${ }^{1}$ Regardless of the type of scholarship engaged in, peer-reviewed publications serve as the primary archival record of academic scholarship. ${ }^{2-4}$ Bibliometrics is a discipline that involves the application of mathematical and statistical methods to scholarly publications. ${ }^{5}$ A number of bibliometric applications have been applied to pharmacy and medicine over the past decade. ${ }^{5}$ In addition, many new, interesting indices have been added that, with time, may provide normative benchmarks to evaluate faculty and researchers within individual disciplines. ${ }^{6,7}$

CEO deans are ultimately responsible for creating a culture that both requires and promotes scholarship at their schools and colleges of pharmacy (SCOP). ${ }^{8}$ In this leadership role, deans must be a role model for faculty in the conceptualization, planning, execution, and writing of a well-thought out project. In addition, deans serve as the overseer of annual faculty evaluations and of faculty tenure and promotion documents. In this capacity, deans

Corresponding Author: Dennis F. Thompson, College of Pharmacy, Southwestern Oklahoma State University, Weatherford, OK 73096. Tel: 580-774-3764. Fax: 580-7747020. E-mail: dennis.thompson@swosu.edu must have a sufficient background in research and scholarship and must have a track record of publications to credibly lead faculty in this area.

In 2012, seven pharmacy deans wrote a paper discussing the need for a renewed focus on research as the number of SCOP in the US continue to expand. ${ }^{9}$ They observed that many of the new SCOP were situated at universities that lacked a significant research infrastructure. This was reflected in the small number of new SCOP that were housed at universities that were Carnegie research designated or hold membership in the Association of American Universities. While acknowledging Boyer's four types of scholarship, this group of deans advocated for a renewed focus by the Academy on the scholarship of discovery. One of the concluding points made by these authors was that the Accreditation Council for Pharmacy Education (ACPE) should more strongly emphasize that all faculty members should be engaged in research and creative activities.

The primary purpose of this research was to characterize the publication records and bibliometric indices of the current CEO deans at the SCOP in the US. The secondary outcome was to compare the dean attributes and SCOP characteristics to the publication metrics of the corresponding dean.

\section{METHODS}

This was a cross-sectional study of the current deans of SCOP in the US as of November 1, 2016. Deans were identified by using the online roster of faculty and 


\section{American Journal of Pharmaceutical Education 2019; 83 (2) Article 6513.}

professional staff available at the American Association of Colleges of Pharmacy website. ${ }^{10}$ Research intensive SCOP were identified using a previously used method. ${ }^{11}$ New SCOP were defined as having received full accreditation after 2007. Public, private, academic health centerbased, and non-academic health center-based SCOP were defined by using the classifications on the PharmCAS website. ${ }^{12}$ The Phase 2 methods of Thompson and Nahata $^{11}$ were used in conducting the Web of Science (WoS) searches and calculating the bibliometric indices using the methods and software programs developed by Soler. ${ }^{13}$ Briefly, the search strategy for this study began with a general search of the author and the geographic state of the SCOP (Example, $\mathrm{au}=$ Smith $\mathrm{J}^{*}$ and $\mathrm{ad}=\mathrm{OH}$ ). This allowed the searcher to identify how the dean generally authored publications (such as Smith J or Smith JP). After identifying under what form the faculty member authored published papers, a specific broad search was done without geographic restriction. These publication files were then captured and screened through the FILTER program to remove homologues. After filtering, the files were compiled and analyzed using the MERIT program. Bibliometric indices calculated by the program included the h-index, m-quotient, total citations, citations/paper, citations/year, and creativity and productivity indices. These data were then entered into a Microsoft Excel (Redmond, WA) spreadsheet for further analysis. The estimated accuracy and precision of the methodology was $95 \%$ and $98 \%$, respectively. ${ }^{14}$ In addition, data were double-checked using information in biographies, and press releases when available on the individual SCOP website. Further checking was done through biographical research websites such as ResearchGate, ResearcherID, LinkedIn, and others. Lastly, viewing of the original research articles was performed if homologues were still in question. ${ }^{15}$

The bibliometric indices used in this study and their application to academic pharmacy have recently been reviewed. ${ }^{6}$ The h-index, ${ }^{16}$ probably the best known of these metrics, is defined as follows: if a faculty member has an h-index of 20, the faculty member has published 20 papers, each of which has $>20$ citations. The h-index combines both quantitative and qualitative aspects in a single whole number. However, h-index favors faculty who have built a large collection of papers and citations. The m-quotient normalizes the h-index by dividing the number of years involved in research, usually starting with the faculty members' first publication ( $m=h /$ years). This allows comparisons between faculty regardless of years of publishing. ${ }^{6}$

Data were initially compiled into Excel spreadsheets and analyzed using descriptive statistics. Because of the highly skewed nature of bibliometric data, the KruskalWallis analysis of variance for nonparametric data was used to assess differences between groups. The a priori level of significance was set at $p<.01$.

\section{RESULTS}

There were 136 deans identified through the online roster. Ten deans were from schools outside the US or from US territories and were not considered in the analysis. Two deans were interim at the time and were also excluded from the study. This left 124 SCOP deans, which were analyzed in the study. This study evaluated 7,434 publications from 124 deans. Table 1 is a compilation of the bibliometric parameters measured for all deans. Both means and medians are listed for each parameter, although considering the skewed nature of the data, median values are more representative. Standard deviations on the means are large and reflect the wide variation seen in the data. Thirty-four deans (27\%) accounted for approximately $80 \%(n=5,981)$ of all publications. Table 2 provides insight into the metrics and indices based on dean attributes, such as gender, terminal degree, academic discipline, and SCOP characteristics. Most of the degree and discipline data are statistically significant, however, none of the differences in gender reached statistical significance. In general, deans with $\mathrm{PhD}$ degrees tended to outperform their PharmD counterparts for almost all publication parameters. Similarly, basic science faculty (medicinal chemistry, pharmaceutics, and pharmacology) had higher indices than pharmacy practice or pharmacy administration disciplines. Significant differences were found between public and private, research-intensive and teaching-intensive, academic health center-based and non-academic health center-based SCOP in all the bibliometric indices calculated. Figure 1 presents individual data on h-index values for deans at public SCOP and private SCOP. Six deans $(5 \%)$ were found with no publications on the WoS database and $19(15 \%)$ with h-indices of $<1$ indicating little to no impact on the scientific, clinical, or

Table 1. Publication Metrics and Indices of Pharmacy Deans

\begin{tabular}{lcrl}
\hline Publication Attributes & M (SD) & Median & Range \\
\hline Number of Publications & $60.0(94.3)$ & 20.5 & $0-599$ \\
Publications/year & $0.5(0.4)$ & 0.4 & $0-2.0$ \\
h-index & $13.3(14.6)$ & 8.0 & $0-72$ \\
m-Quotient & $2.0(2.52)$ & 1.0 & $0-14.6$ \\
Total Citations & $1,394.4(3,068)$ & 223.5 & $0-23,407$ \\
Citations/year & $431.0(80.8)$ & 11.2 & $0-570.9$ \\
Average citations/paper & $13.5(12.1)$ & 11.8 & $0-74.7$ \\
Productivity & $394.4(929)$ & 69.3 & $0-7,656$ \\
Creativity & $174.1(432)$ & 23.3 & $0-3,235$ \\
\hline
\end{tabular}


American Journal of Pharmaceutical Education 2019; 83 (2) Article 6513.

Table 2. Publication Metrics and Indices of Pharmacy Dean Attributes and Institutions

\begin{tabular}{|c|c|c|c|c|}
\hline Metric & Variable & Mean & Median & $p$ \\
\hline $\begin{array}{l}\text { Number of Publications } \\
\text { (Lifetime) }\end{array}$ & $\begin{array}{l}\text { Male vs Female } \\
\text { PhD vs PharmD } \\
\text { Public vs Private } \\
\text { AHC vs n-AHC } \\
\text { Research vs Teaching } \\
\text { Older vs Newer } \\
\text { Med Chem } \\
\text { Pharmaceutics } \\
\text { Pharmacology } \\
\text { Pharmacy Practice } \\
\text { Pharmacy Admin }\end{array}$ & $\begin{array}{r}61.0 \text { vs } 56.4 \\
83.4 \text { vs } 40.0 \\
98.3 \text { vs } 27.3 \\
112.4 \text { vs } 33.1 \\
109.8 \text { vs } 25.2 \\
78.1 \text { vs } 23.2 \\
94.1 \\
97.7 \\
98.1 \\
37.8 \\
44.8\end{array}$ & $\begin{array}{c}20.5 \text { vs } 21.0 \\
35 \text { vs } 15 \\
79 \text { vs } 11 \\
92.5 \text { vs } 12.5 \\
85 \text { vs } 11 \\
32 \text { vs } 10 \\
19.5 \\
89 \\
79 \\
13 \\
17\end{array}$ & $\begin{array}{l}\mathrm{NS} \\
.01 \\
.0001 \\
.0001 \\
.0001 \\
.001\end{array}$ \\
\hline Publications/year & $\begin{array}{l}\text { Male vs Female } \\
\text { PhD vs PharmD } \\
\text { Public vs Private } \\
\text { AHC vs n-AHC } \\
\text { Research vs Teaching } \\
\text { Older vs Newer } \\
\text { Med Chem } \\
\text { Pharmaceutics } \\
\text { Pharmacology } \\
\text { Pharmacy Practice } \\
\text { Pharmacy Admin }\end{array}$ & $\begin{array}{c}2.0 \text { vs } 2.0 \\
2.6 \text { vs } 1.5 \\
3.4 \text { vs } 1.3 \\
3.4 \text { vs } 1.3 \\
3.4 \text { vs } 1.0 \\
2.5 \text { vs } 1.0 \\
2.8 \\
3.4 \\
2.9 \\
1.4 \\
1.5\end{array}$ & $\begin{array}{l}0.9 \text { vs } 1.5 \\
1.5 \text { vs } 1.5 \\
2.3 \text { vs } 0.7 \\
2.8 \text { vs } 0.7 \\
2.8 \text { vs } 0.7 \\
1.5 \text { vs } 0.7 \\
0.8 \\
2.7 \\
1.8 \\
0.8 \\
0.6\end{array}$ & $\begin{array}{l}\mathrm{NS} \\
\mathrm{NS} \\
.0001 \\
.0001 \\
.0001 \\
.01\end{array}$ \\
\hline h-index & $\begin{array}{l}\text { Male vs Female } \\
\text { PhD vs PharmD } \\
\text { Public vs Private } \\
\text { AHC vs n-AHC } \\
\text { Research vs Teaching } \\
\text { Older vs Newer } \\
\text { Med Chem } \\
\text { Pharmaceutics } \\
\text { Pharmacology } \\
\text { Pharmacy Practice } \\
\text { Pharmacy Admin }\end{array}$ & $\begin{array}{c}13.9 \text { vs } 11.0 \\
18.2 \text { vs } 9.1 \\
20.5 \text { vs } 7.1 \\
22.1 \text { vs } 8.8 \\
22.6 \text { vs } 6.8 \\
16.3 \text { vs } 7.0 \\
17.5 \\
23.1 \\
23.9 \\
8.7 \\
7.1\end{array}$ & $\begin{array}{l}8.0 \text { vs } 8.5 \\
13 \text { vs } 6 \\
19 \text { vs } 5 \\
20 \text { vs } 6 \\
22 \text { vs } 5 \\
12 \text { vs } 5 \\
9.5 \\
23 \\
22 \\
5.5 \\
5.5\end{array}$ & $\begin{array}{l}\mathrm{NS} \\
.01 \\
.0001 \\
.0001 \\
.0001 \\
.001\end{array}$ \\
\hline m-Quotient & $\begin{array}{l}\text { Male vs Female } \\
\text { PhD vs PharmD } \\
\text { Public vs Private } \\
\text { AHC vs n-AHC } \\
\text { Research vs Teaching } \\
\text { Older vs Newer } \\
\text { Med Chem } \\
\text { Pharmaceutics } \\
\text { Pharmacology } \\
\text { Pharmacy Practice } \\
\text { Pharmacy Admin }\end{array}$ & $\begin{array}{c}0.5 \text { vs } 0.5 \\
0.6 \text { vs } 0.4 \\
0.6 \text { vs } 0.4 \\
0.7 \text { vs } 0.4 \\
0.5 \text { vs } 0.3 \\
0.6 \text { vs } 0.4 \\
0.6 \\
0.8 \\
0.8 \\
0.4 \\
0.3\end{array}$ & $\begin{array}{l}0.4 \text { vs } 0.4 \\
0.5 \text { vs } 0.3 \\
0.5 \text { vs } 0.3 \\
0.7 \text { vs } 0.3 \\
0.7 \text { vs } 0.3 \\
0.5 \text { vs } 0.3 \\
0.5 \\
0.7 \\
0.8 \\
0.3 \\
0.2\end{array}$ & $\begin{array}{l}\text { NS } \\
.01 \\
.001 \\
.0001 \\
.0001 \\
\text { NS }\end{array}$ \\
\hline
\end{tabular}


American Journal of Pharmaceutical Education 2019; 83 (2) Article 6513.

Table 2. (Continued)

\begin{tabular}{|c|c|c|c|c|}
\hline Metric & Variable & Mean & Median & $p$ \\
\hline $\begin{array}{l}\text { Total Citations } \\
\text { (Lifetime) }\end{array}$ & $\begin{array}{l}\text { Male vs Female } \\
\text { PhD vs PharmD } \\
\text { Public vs Private } \\
\text { AHC vs n-AHC } \\
\text { Research vs Teaching } \\
\text { Older vs Newer } \\
\text { Med Chem } \\
\text { Pharmaceutics } \\
\text { Pharmacology } \\
\text { Pharmacy Practice } \\
\text { Pharmacy Admin }\end{array}$ & $\begin{array}{c}1,542 \text { vs } 877.6 \\
2,234 \text { vs } 629 \\
2,274.4 \text { vs } 645.8 \\
2,521.9 \text { vs } 817.0 \\
2,574 \text { vs } 570 \\
1,870.1 \text { vs } 431.5 \\
3,030 \\
2,029 \\
2753 \\
591 \\
848\end{array}$ & $\begin{array}{c}223.4 \text { vs } 208.5 \\
560 \text { vs } 1,234 \\
1,122 \text { vs } 83 \\
1,292 \text { vs } 127.5 \\
1,563 \text { vs } 83 \\
415 \text { vs } 81 \\
498.5 \\
1,702 \\
1,197 \\
122 \\
123\end{array}$ & $\begin{array}{l}\mathrm{NS} \\
.001 \\
.0001 \\
.0001 \\
.0001 \\
.01\end{array}$ \\
\hline Citations/year & $\begin{array}{l}\text { Male vs Female } \\
\text { PhD vs PharmD } \\
\text { Public vs Private } \\
\text { AHC vs n-AHC } \\
\text { Research vs Teaching } \\
\text { Older vs Newer } \\
\text { Med Chem } \\
\text { Pharmaceutics } \\
\text { Pharmacology } \\
\text { Pharmacy Practice } \\
\text { Pharmacy Admin }\end{array}$ & $\begin{array}{r}61.0 \text { vs } 56.4 \\
83.4 \text { vs } 40.0 \\
98.3 \text { vs } 27.3 \\
112.4 \text { vs } 33.1 \\
109.8 \text { vs } 25.2 \\
78.1 \text { vs } 23.2 \\
94.1 \\
97.7 \\
98.1 \\
37.8 \\
44.7\end{array}$ & $\begin{array}{c}20.5 \text { vs } 21.0 \\
35 \text { vs } 15 \\
79 \text { vs } 11 \\
92.5 \text { vs } 12.5 \\
85 \text { vs } 11 \\
32 \text { vs } 10 \\
19.5 \\
8.9 \\
7.9 \\
13 \\
17\end{array}$ & $\begin{array}{l}\text { NS } \\
.01 \\
.0001 \\
.0001 \\
.0001 \\
.001\end{array}$ \\
\hline Average Citations/paper & $\begin{array}{l}\text { Male vs Female } \\
\text { PhD vs PharmD } \\
\text { Public vs Private } \\
\text { AHC vs n-AHC } \\
\text { Research vs Teaching } \\
\text { Older vs Newer } \\
\text { Med Chem } \\
\text { Pharmaceutics } \\
\text { Pharmacology } \\
\text { Pharmacy Practice } \\
\text { Pharmacy Admin }\end{array}$ & $\begin{array}{c}47.7 \text { vs } 27.6 \\
68.3 \text { vs } 20.3 \\
67.9 \text { vs } 22.0 \\
75.7 \text { vs } 28.0 \\
77.2 \text { vs } 10.3 \\
56.1 \text { vs } 16.8 \\
91 \\
69.4 \\
81.8 \\
19.1 \\
25.9\end{array}$ & $\begin{array}{c}10.3 \text { vs } 11.8 \\
24.4 \text { vs } 5.9 \\
32.3 \text { vs } 4.6 \\
38.9 \text { vs } 5.3 \\
45.9 \text { vs } 4.6 \\
16.4 \text { vs } 6.0 \\
19.1 \\
51.4 \\
46.5 \\
4.9 \\
4.2\end{array}$ & $\begin{array}{l}\text { NS } \\
.001 \\
.0001 \\
.0001 \\
.0001 \\
.01\end{array}$ \\
\hline $\begin{array}{l}\text { Productivity } \\
\text { (Lifetime) }\end{array}$ & $\begin{array}{l}\text { Male vs Female } \\
\text { PhD vs PharmD } \\
\text { Med Chem } \\
\text { Pharmaceutics } \\
\text { Pharmacology } \\
\text { Pharmacy Practice } \\
\text { Pharmacy Admin }\end{array}$ & $\begin{array}{c}430 \text { vs } 271.8 \\
637.7 \text { vs } 172 \\
546.5 \\
641.9 \\
972.4 \\
161.4 \\
161.6\end{array}$ & $\begin{array}{c}70.6 \text { vs } 65.6 \\
149 \text { vs } 36.9 \\
86.3 \\
520.5 \\
383.1 \\
30.9 \\
40.4\end{array}$ & $\begin{array}{l}\mathrm{NS} \\
.01\end{array}$ \\
\hline $\begin{array}{l}\text { Creativity } \\
\text { (Lifetime) }\end{array}$ & $\begin{array}{l}\text { Male vs Female } \\
\text { PhD vs PharmD } \\
\text { Med Chem } \\
\text { Pharmaceutics } \\
\text { Pharmacology } \\
\text { Pharmacy Practice } \\
\text { Pharmacy Admin }\end{array}$ & $\begin{array}{c}61.0 \text { vs } 56.4 \\
83.4 \text { vs } 40.0 \\
268.1 \\
256.1 \\
426.7 \\
68.9 \\
81.0\end{array}$ & $\begin{array}{c}20.5 \text { vs } 21.0 \\
35 \text { vs } 15 \\
55.7 \\
202.0 \\
166.6 \\
12.0 \\
13.5\end{array}$ & $\begin{array}{r}\mathrm{NS} \\
.001\end{array}$ \\
\hline
\end{tabular}

Number of Participants: Male $=96$, Female $=28, \mathrm{PhD}=61$, PharmD $=58$, Other $=5, \mathrm{MC}($ Medicinal Chemistry $)=12, \mathrm{PC}(\mathrm{Pharmacology})=24$, PT $($ Pharmaceutics $)=10$, PP $($ Pharmacy Practice $)=62$, PA $($ Pharmacy Administration $)=16$, Public $=57$, Private $=67$, AHC $($ Academic Health Center $)=42$, n-AHC $($ Non-Academic Health Center $)=82$, Research intensive $=51$, Teaching intensive $=73$, Older $=83$, Newer $=41$ 


\section{American Journal of Pharmaceutical Education 2019; 83 (2) Article 6513.}

administrative sciences. Figure 2 provides a comprehensive review of lifetime publication rates of several key groups of pharmacy faculty from data generated in this study and previous studies: pharmacy deans (data from the current study, not the previous study), ${ }^{17}$ pharmacy practice chairs, ${ }^{18}$ pharmaceutical science faculty from research-intensive universities, ${ }^{11}$ and AACP Volwiler research award winners. ${ }^{19}$

\section{DISCUSSION}

There is significant diversity in the quantity and quality of publications produced by deans. This may reflect the equally diverse number of SCOP. The CEO deans may mirror the mission of their affiliated SCOP, be that primarily teaching or research. ACPE has broad scholarship requirements for deans. Current ACPE Standard 8.2 states, "The dean is qualified to provide leadership in pharmacy professional education and practice, research and scholarship, and professional and community service. ${ }^{20}$ It appears all current deans meet this standard since all the corresponding SCOP analyzed are accredited, even though six deans (5\%) have no journal publications in the WoS database. While it is possible that these deans had publications not indexed in the WoS database, those journals outside the WoS database suggest a lesser impact in the scientific community. WoS covers approximately 10,000 journals in the scientific, administrative, and clinical disciplines that reflect a significant journal impact factor for that discipline. ${ }^{21}$ Recently, the American Journal of Pharmaceutical Education published papers regarding a parallel issue of whether a dean should be a pharmacist; an issue that also extends beyond current ACPE standards. ${ }^{22-24}$ Perhaps a similar debate might be appropriate for the research and scholarship requirements for a dean.

Several studies have found few SCOP or groups of faculty members who have minimal scholarship. In 2007, Coleman and colleagues discovered two SCOP where pharmacy practice faculty produced zero publications from 2001 to 2003 and four SCOP that averaged 0.1 publications/faculty. ${ }^{25}$ Bloom and Schlesselman found one pharmaceutical sciences department (average 12.2 faculty/department) that produced zero publications from 2010 to 2013 and 10 departments contributing $<10$ publications during this period. ${ }^{26}$ Other studies have found $2 \%$ of deans, ${ }^{17} 3 \%$ of pharmacy practice chairs, ${ }^{18} 22 \%$ of pharmaceutical science faculty, ${ }^{11}$ and $57 \%$ of experiential directors ${ }^{27}$ who did not publish during the timeframes of

h-index Values for Public $\square$ vs. Private $\square$ SCOP Deans

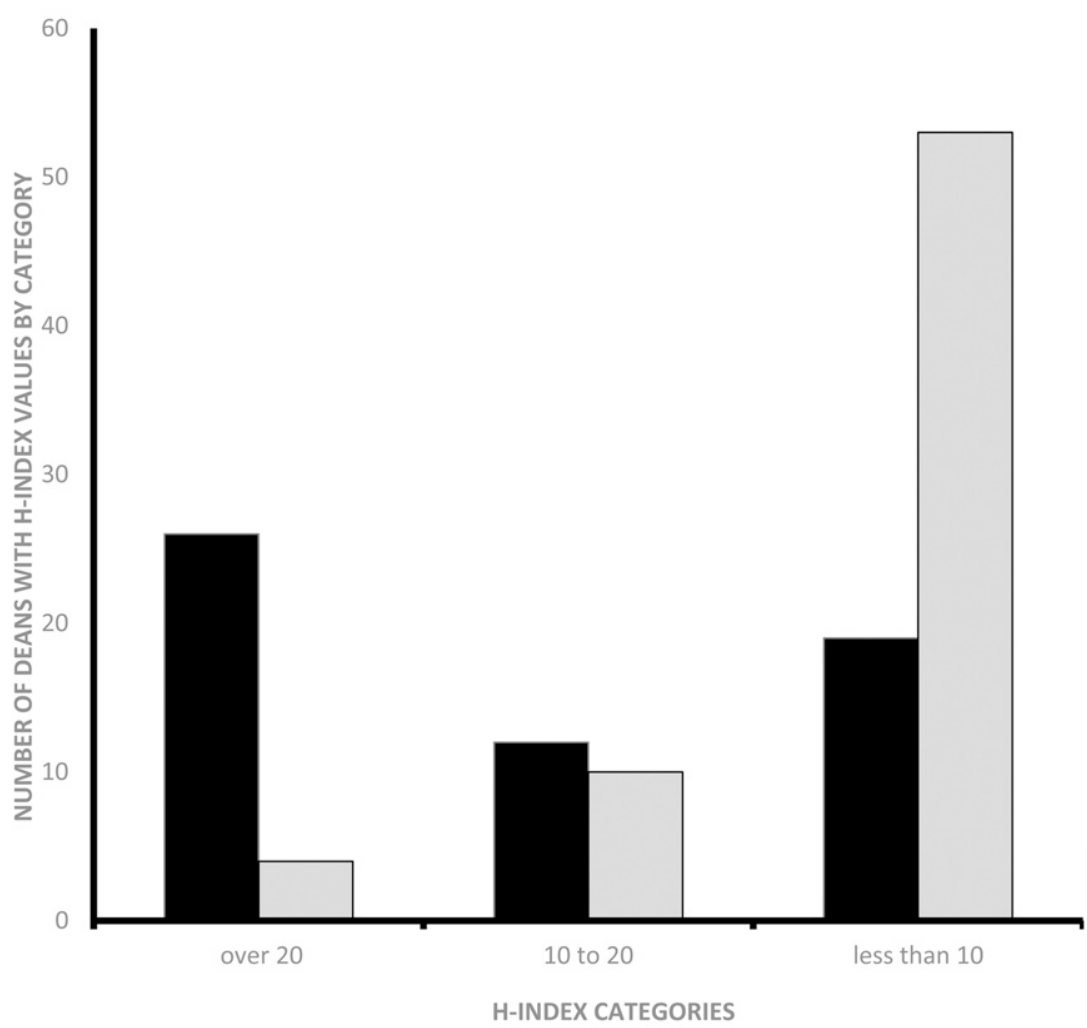

Figure 1. h-index Values for Public vs. Private SCOP Deans 


\section{American Journal of Pharmaceutical Education 2019; 83 (2) Article 6513.}

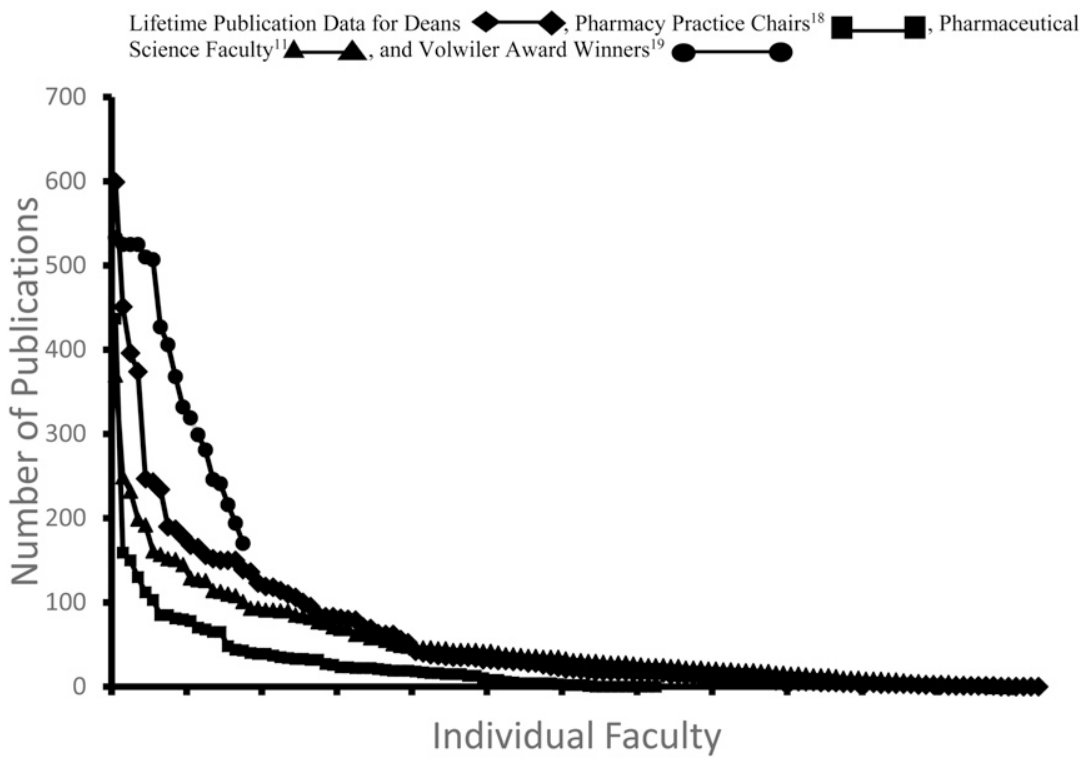

Figure 2. Lifetime Publication Data for Deans, Pharmacy Practice Chairs18, Pharmaceutical Science Faculty11, and Volwiler Award Winners 19

the studies involved. It appears the current state of faculty scholarship may not be fulfilling the statement ${ }^{28}$ of AACP's Research and Graduate Affairs Committee from 1995, which affirmed "every full-time faculty member is expected to participate in research (the generation and/or application of new knowledge) and its dissemination to an extent consistent with the mission of the school and college."

Thompson and Callen evaluated the publication records of 86 deans in $2007 .{ }^{17}$ Their data were generated from the Medline database rather than the WoS database, which was used in the current study. Despite the 10-year difference in data collection and using a different database, there are still consistent parallels between the 2007 study and the present findings. Deans from public schools had more publications than deans from private schools in the 2007 study $(p<.01)$ and deans from established schools ( $>10$ years $)$ had more publications than deans from newer schools $(p<.01)$. Twenty percent of deans accounted for $61 \%$ of all the publications in the earlier study while $19 \%$ of deans accounted for $60 \%$ in the current study. Deans publishing five or fewer lifetime publications were $23 \%$ in the 2007 study and 24\% in the current study. These skewed distributions are generally consistent with Lotka's law, ${ }^{29}$ one of the foundational laws of bibliometrics, which generally follow a roughly " $80-20$ " rule where $20 \%$ of authors (or faculty members) produce $80 \%$ of a group's publications.

Gender disparities in academic faculty continue to persist, particularly in the science disciplines. ${ }^{30-36}$ There continues to be few female full professors along with continuing inequalities in salary, research funding, publications, and administrative advancement. While women now outnumber men in both undergraduate and graduate students in many countries, there are still fewer women in most academic disciplines than men. ${ }^{33,34}$ These gender disparities have been highlighted in pharmacy. ${ }^{34,35}$ In the 2002-2003 academic year, 12 of 81 (15\%) SCOP deans were female, ${ }^{34}$ in 2009-2010 academic year, 24 of 93 $(26 \%)$ were female, ${ }^{35}$ and in this study, 28/124 (23\%) were female. While the percentage of female deans has increased slightly in the preceding 14 years, underrepresentation in the dean ranks continues. In contrast to other research that have found a gap in publications by female faculty vs males, ${ }^{11,36}$ our data show no statistical difference by gender in the current sample of deans. This may suggest, at least in the important parameter of scholarship, that female deans have earned their position by being both as productive and creative as their male counterparts.

Leadership requires a wide variety of skills. ${ }^{37,38}$ As a CEO dean, it is impossible to be an expert in all areas of pharmaceutical science, practice, management, leadership, budgeting, fundraising, strategic planning, and human resources. An analogy might be drawn from the arena of sports coaching. To be a great coach, is it necessary to have been a great athlete? Certainly, our experience tells us that not every successful major league baseball coach hit .300 as a player or won the Cy Young award. Rather, all successful coaches have the leadership skills and innate ability to recognize talent, communicate goals, obtain resources, and inspire the best in their players. It is not uncommon for executives at large corporations to move from one CEO position to another CEO position in a completely different field and still achieve success in the new position. Is the concept of a pharmacy dean being a highly published scholar an outdated construct? Further 


\section{American Journal of Pharmaceutical Education 2019; 83 (2) Article 6513.}

dialogue involving all stakeholders in the Academy will be necessary to fully resolve this issue.

One of the limitations of this study includes the use of the WoS database. While covering many journals in the scientific, administrative, and clinical disciplines, it is not comprehensive and some professional and scientific journals relevant to pharmacy and pharmaceutical sciences are not covered by WoS. While other databases might yield different results, WoS continues to be the single best source of bibliometric data and is the only database with comprehensive historical data and author addresses. ${ }^{39,40}$ Homologues, defined as authors with the same name but in different disciplines, are always a potential problem in bibliometric searches. ${ }^{15,41}$ The use of the software programs developed by Soler has inherent accuracy of $95 \%$ and precision of $98 \%{ }^{14}$ The addition of public websites, researcher bibliographic information, and visually inspecting authorinstitution agreement should improve both of these figures. In many cases, dean curricula vitae were available online and could be cross-indexed against the WoS searchers. Finally, source documents can have errors which can often be identified through cross-checking, but not always. ${ }^{42}$

\section{CONCLUSION}

Current CEO pharmacy deans are highly varied in the number of lifetime publications recorded in the Web of Science (WoS) database. Bibliometric indices, such as the h-index, were also highly variable. Statistically significant differences were found between deans affiliated with academic health centers vs non-academic health centers, public vs private institutions, and teaching-intensive vs research-intensive SCOP. Although no differences were found in gender, deans with $\mathrm{PhD}$ degrees tended to have higher bibliometric indices than deans with PharmD degrees. A small number of deans had little to no publication record on the WoS database.

\section{REFERENCES}

1. Boyer EL. Scholarship Reconsidered: Priorities of the Professoriate. Princeton, NJ: The Carnegie Foundation for the Advancement of Teaching; 1990.

2. Kennedy RH, Gubbins PO, Luer M, Reddy IK, Light KE. Developing and sustaining a culture of scholarship. Am J Pharm Educ. 2003;67(3):Article 92.

3. Smesny AL, Williams JS, Brazeau GA, Weber RJ, Matthews HW, Das SK. Barriers to scholarship in dentistry, medicine, nursing, and pharmacy practice faculty. Am J Pharm Educ. 2007;71(5):Article 91. 4. Leslie SW, Corcoran GB, MacKichan JJ, Undie AS, Vanderveen RP, Miller KW. Pharmacy scholarship reconsidered: the report of the 2003-2004 research and graduate affairs committee. Am J Pharm Educ. 2004;68(3):Article S6.

5. Thompson DF, Walker CK. A descriptive and historical review of bibliometrics with applications to medical science. Pharmacotherapy. 2015;35(6):551-559.
6. Thompson DF, Callen EC, Nahata MC. New indicies in scholarship assessment. Am J Pharm Educ. 2009;73(6):Article 111. 7. Bosso JA, Chisholm-Burns M, Nappi J, Gubbins PO, Ross LA. Benchmarking in academic pharmacy departments. Am J Pharm Educ. 2010;74(8):Article 140.

8. Kehrer JP, Svensson CK. Advancing pharmacist scholarship and research within academic pharmacy. Am J Pharm Educ. 2012;76(10): Article 187.

9. Bauman JL, Ascione FJ, Brueggemeier RW, Letendre DE, Roberts JC, Speedie MK, Svensson CK. Maintaining pharmacy education's research focus as the academy expands. Am J Pharm Educ. 2012;76(8):Article 144.

10. American Association of Colleges of Pharmacy. US schools and colleges of pharmacy. AACP institutional membership. https://www. aacp.org/article/aacp-institutional-membership. Accessed May 1, 2017. 11. Thompson DF, Nahata MC. Pharmaceutical science faculty publication records at research-intensive pharmacy colleges and schools. Am J Pharm Educ. 2012;76(9): Article 173.

12. American Association of Colleges of Pharmacy, Alexandria, VA: Pharmacy College Application Service: PharmCAS. http:// www.aacp.org/resources/student/pharmacyforyou/Pages/ PharmCAS.aspx. Accessed May 1, 2017.

13. Soler JM. A rational indicator of scientific creativity. http://arxiv. org/abs/physics/0608006. Accessed May 1, 2017.

14. Thompson DF. Evaluating the Soler Method in Bibliometric Searches. [Abstract]. Am J Pharm Educ. 2010;74(5): Article 96. 15. Soler JM. Separating the articles of authors with the same name. Scientometrics. 2007;72(2):281-290.

16. Hirsch JE. An index to quantify an individual's scientific research output. Proc Natl Acad Sci. 2005;102:16569-16572. 17. Thompson DF, Callen EC. Publication patterns of Pharmacy Deans. [Letter]. Ann Pharmacother. 2008;42:142-143.

18. Thompson DF, Callen EC, Nahata MC. Publication metrics and record of pharmacy practice chairs. Ann Pharmacother. 2009;43:268-275. 19. Thompson DF, Callen ED. Bibliometric analysis of Volwiler awardees. [Abstract]. Am J Pharm Educ. 2009;73(4):39.

20. Accreditation Council for Pharmacy Education. Accreditation standards and guidelines for the professional program in pharmacy leading to the doctor of pharmacy degree. https://www.acpe-accredit. org/pharmd-program-accreditation/. Accessed May 1, 2017.

21. Web of Science Fact Page. http://wokinfo.com/products_tools/ multidisciplinary/webofscience/. Accessed November 7, 2011. 22. Svensson CK. Should a pharmacy dean be a pharmacist? Am J Pharm Educ. 2015;79(3): Article 32.

23. Bell HS. Should a pharmacy dean be a pharmacist? Am J Pharm Educ. 2015:79(3): Article 33.

24. Garcia GA. Respones to Viewpoint - Point/Counterpoint: Should a pharmacy dean be a pharmacist? Am J Pharm Educ. 2015;79(9): Article 144.

25. Coleman CI, Schlesselmann L, White CM. Journal publications by pharmacy practice faculty evaluated by institution and region of the United States (2001-2003). Pharm Pract. 2007;5(4):151-156. 26. Bloom TJ, Schlesselmann L. Publication rates for pharmaceutical sciences faculty members at nonresearch-intensive US schools of pharmacy. Am J Pharm Educ. 2015;79(9): Article 136.

27. Danielson J, McElroy S. Quantifying published scholarly works of experiential education directors. Am J Pharm Educ. 2013;77(8): Article 167.

28. Speedie MK, Brouwer KL, Hak LJ, Lathers CM, Thomas J, Smith MD. Chair report for the Research and Graduate Affairs Committee. Am J Pharm Educ. 1995;59:19S-23S. 


\section{American Journal of Pharmaceutical Education 2019; 83 (2) Article 6513.}

29. Lotka AJ. The frequency distribution of scientific productivity. $J$ Wash Acad Sci. 1926;16:317-323.

30. West JD, Jacquet J, King MM, Correll SJ, Bergstrom CT. The role of gender in scholarly authorship. PLOS ONE 2013;8(7):e66212. 31. Sugimoto CR. Global gender disparities in science. Nature. 2013;504:211-213.

32. Chisholm-Burns MA, Spivey CA, Billheimer D, et al. Multiinstitutional study of women and underrepresented minority faculty members in academic pharmacy. Am J Pharm Educ. 2012;76(1): Article 7.

33. Svarstad BL, Draugalis JR, Meyer SM, Mount JK. The status of women in pharmacy education: persisting gaps and issues. $\mathrm{Am} \mathrm{J}$ Pharm Educ. 2004;68(3): Article 79.

34. Draugalis JR, Plaza CM. A 20-year perspective on preparation strategies and career planning of pharmacy deans. Am J Pharm Educ. 2010;74(9): Article 162.

35. Draugalis JR, Plaza CM, Taylor DA, Meyer SM. The status of women in US academic pharmacy. Am J Pharm Educ. 2014;78(10): Article 178 .
36. Tomei KL, Nahass MM, Husain Q, et al. A gender-based comparison of academic rank and scholarly productivity in academic neurological surgery. J Clin Neurosci. 2014;21:1102-1105. 37. Allen GP, Moore WM, Moser LR, et al. The role of servant leadership and transformational leadership in academic pharmacy. Am J Pharm Educ. 2016;80: Article 113.

38. Boerma M, Coyle EA, Dietrich MA, et al. Are outstanding leaders born or made? Am J Pharm Educ. 2017;81: Article 58. 39. Kulkarni AV, Aziz B, Shams I, Busse JW. Comparisons of citations in Web of Science, Scopus, and Google Scholar for articles published in general medical journals. JAMA. 2009;302(10):1092-1096.

40. Bar-Ilan J. Which h-index? A comparison of WoS, Scopus, and Google Scholar. Scientometrics. 2008;74(2):257-271.

41. Smalheiser NR, Torvik VI. Author name disambiguation. In: Cronin B, ed. Annual Review of Information Science and Technology. Vol 43. Malden, MA: John Wiley \& Sons; 2009; 287-313.

42. MacRoberts MH, MacRoberts BR. Problems of citation analysis: a critical review. J Am Soc Info Sci. 1989;40:342-349. 